\title{
Keratinizing Nasal Cavity Squamous Cell Carcinoma
}

National Cancer Institute

\section{Source}

National Cancer Institute. Keratinizing Nasal Cavity Squamous Cell Carcinoma. NCI

Thesaurus. Code C54285.

A squamous cell carcinoma that arises from the nasal cavity and is characterized by prominent production of keratin. 